SITES: NEW SERIES $\cdot$ VOL 13 NO $2 \cdot 2016$

DoI: http://dx.doi.org/10.11157/sites-vol13iss2id321

- ARTICLE -

\author{
THE POLITICS OF LOCATION: \\ BEING A NATIVE ANTHROPOLOGIST AMONG WESTERN \\ INTERLOCUTORS IN INDIA
}

Tuhina Ganguly ${ }^{1}$

\begin{abstract}
This paper examines the politics of doing fieldwork as a 'native' i.e. Indian anthropologist among Western interlocutors in India. Focusing on the interrelations between the Indian anthropologist and (predominantly) Western participants, this shows the complex nature of insider/outsider and nativel Western location(s). While pointing out the multiple and shifting locations inhabited by the author and the interlocutors, the paper also highlights the ways in which such fluidity negotiates with the construct of the authentic native. The fixity of the mythical figure of the native made it difficult for the author to claim undisputed insidership. However, in critiquing the construction of the native as a fixed, immobile category, the author is nevertheless mindful that counter-constructions of the native as hybrid and hypermobile overlook the privileged position of postcolonial academics. Ultimately, the paper argues that acknowledging the specificities of one's location shatters the myth of the native as a singular category.
\end{abstract}

Keywords: Authenticity; location; native anthropologist; postcolonial elite; Puducherry

\title{
INTRODUCTION
}

Questions of inclusion and exclusion, being an insider or outsider, have long been important issues in the practice of doing fieldwork in anthropology (O'Reilly 2009). Concerns about 'going native' or not being 'native' enough have underpinned ethnographic fieldwork since the time of Malinowski who studied the 'exotic other'. In later decades, doing 'anthropology at home' (Jackson 1987) did not lead to an erosion of those concerns either even though anthropologists were ostensibly engaging with people from and in their own 
countries, sharing a language and similar world views. Several anthropologists have pointed to the fractured, situated nature of doing fieldwork at home whereby conditions of birth, or shared ethnicity with research participants, combined with one's institutional position as observer/anthropologist, place them as native-strangers among their 'own' people (Jahan 2014; Narayan 1993). Such issues and anxieties, which are simultaneously issues regarding representation and knowledge-making, continue to be relevant for anthropologists as we grapple with coming to terms with people and situations in fieldwork whether at home or abroad. However, in this paper I try to go beyond the binary of fieldwork at home/abroad by reflecting on the implications of doing fieldwork as an Indian anthropologist in India, at home so to speak, among primarily long term Western spiritual seekers ${ }^{2}$ in Puducherry, some of whom have been living there for more than three decades.

The issues discussed here revolve around the politics of location(s) 'insider'/'outsider' and 'native' anthropologist/Western participants - in the everyday, intersubjective world of the field as well as wider political structures relating to nation-states and citizenship within which we are necessarily implicated. As an Indian or native anthropologist engaging with a predominantly Western population of long term residents in and frequent travellers to Puducherry, was I an insider there or an outsider? Who or what was I an insider to? What about the people I was engaging with, were they insiders or outsiders?

These questions further relate to the subject position of the 'native informant'. As Spivak (1999) argues, in anthropology, the native informant serving as the ethnographer's insider-guide to the culture under study has been absolutely crucial to the discipline, 'In that discipline, the native informant, although denied autobiography as it is understood in the Northwestern European tradition (codename "West"), is taken with utmost seriousness. He (and occasionally she) is a blank, though generative of a text of cultural identity that only the West (or a Western-model discipline) could inscribe' (6). Had the tables somehow turned in my case whereby European and North American interlocutors now occupied the (im)possible perspective, as Spivak puts it, of the native informant for the benefit of the native anthropologist in her home country? As I try to show in this paper, matters were rather complicated due to some of my interlocutors' implicit claims of being native to - in the sense of having intimate knowledge of something - the spiritual world in Puducherry or India in general based on their adaptation-appropriation of (what they think) characteristics of the authentic Indian/native (ought to be). Others rejected a position of absolute insidership claiming a rather hybrid position for themselves 
which was nevertheless charted out against the figure of the native Indian in the background. I argue that while the researcher and interlocutors occupy multiple positions of insider and outsider at different times and in different contexts (Ryan 2015), in my case, such multiplicity nevertheless was often enacted against the fixity of the authentic native. My own position as an Indian researcher studying in New Zealand grappled with such multiple positioning whereby my authenticity as an Indian often came under scrutiny not least because my apparent ease with life in New Zealand seemed to be testimony to my 'Westernisation'. Thus, the politics of location as emergent in my engagements with several interlocutors entailed a dialectic between fluidity of subject positions in the everyday context of fieldwork and fixity of the politically redolent but abstract ideal of the native.

I shall, in the first section, give a brief background of the emergence of the native anthropologist and issues of inside knowledge related to the native anthropologist's presumed intimacy with the culture and people. I argue that theories on/of native or indigenous anthropology presume that native anthropologists do fieldwork among native populations although such populations are seen as being heterogeneous with 'multiplex identity' (Narayan 1993). Going a step further, it needs to be recognised that leisure travel and migration patterns now easily make non-native populations 'available' to native anthropologists at home which necessarily compels us to re-think insider/outsider positionalities even when doing anthropology at home. In the next section, situating Puducherry within trajectories of domestic and, especially, international migration sets the scene for detailing my encounters with Western spiritual seekers or practitioners. Following that, I extend analysis of researcher-researched positionalities to fieldwork engagements with my interlocutors to demonstrate the irresolvable contradictions of our locations and its political implications.

\section{NATIVE ANTHROPOLOGY}

Native anthropologists are anything but recent entrants to the discipline. Young and Meneley discuss the training of native anthropologists by Boas. 'As a way of extending understanding of the "aboriginal mentality", he trained native ethnographers, locals, and women anthropologists [...] he assumed a native ethnographer would achieve a fuller understanding by being a member of the group' (cited in Leibing and McLean 2007, 10-11). By the 1930 Asian origin anthropologists like Fei Hsiao-tung were contributing to the discipline through conducting research at home among fellow nationals (Ben-Ari and Bremen 2005, 27). Although an insider's perspective was simply supposed to offer a more accurate analysis of the indigenous culture, native or indigenous 
anthropology took on a political dimension as non-Western academics began to challenge the hegemony of Western anthropologists studying their culture. In Japan, for instance, Kunio Yanagita insisted that only Japanese academics could truly appreciate Japanese culture such that non-native academics studying Japan were seen as 'outsiders' (Kuwayama 2005). M.N. Srinivas, one of the most illustrious Indian sociologists, wrote that it would be difficult for European anthropologists to gain the same in-depth understanding of Indian society as he had, even after years of research in India (Narayan 1993, 672). Such 'cultural nationalism' (Kuwayama 2005, 98) although meant to reinstate natives as active agents of knowledge production nevertheless left unchallenged the category of the native which ironically has been fetishised by colonialists, Orientalists and Western anthropologists. Frozen in space (Appadurai 1988) and time (Gordon 2013), the native was historically constructed as the authentic embodiment of an undistorted, atemporal history and culture. As Das argues, "The investing of particular cultures with "totalizing visions", in which every individual is seen as representing the whole culture [...] was perhaps never more than an anthropological fantasy' $(1995,4)$. The same issues that haunt the construct 'native' also underlie the category of native anthropologist. In Appadurai's words, the 'metonymic freezing' (cited in Clifford 1997, 24) that produced the native as ahistorical, atemporal and immobilised was also the producer of the native anthropologist as belonging to that same ahistorical, atemporal and immobilised people, therefore capable of representing it most authentically.

Abu-Lughod (1991) and Narayan (1993) strongly critique the essentialising tag of native anthropologist which presumes that one can, as a native, represent the culture as it truly is. Claims about the native anthropologist's absolute authority over the local culture naively irons over differences of gender, class, occupation, and religion which may be more relevant to determining the researcher's position among her participants than shared ethnicity and/or nationality (Morosanu 2015). Fahim and Helmer argue that the broad category of "indigenous anthropologist" obscures the fact that indigenous anthropologists find themselves in a great variety of positions vis-à-vis the local groups that affect their self-perceived roles and the expectations of the local community' (1980, 647). Further, just like the anthropologist, participants too occupy multiple subject positions in society such that, '... people born within a society can be simultaneously both insiders and outsiders, just as those born elsewhere can be outsiders and, if they are lucky, insiders too' (Narayan 1993, 678). Thus, Halstead doing fieldwork in Guyana among her 'own' people evocatively writes that her participants viewed her as both familiar and outsider, 'The boundaries of insider-outsider, far from being rigid had stretched to accommodate their 
expectations and contradictory cultural performances [of at times expressing their indigeneity while at other times disavowing it], a multiplicity of identity movements' (Halstead 2001, 311, parenthesis mine). Narayan recalls constantly negotiating with others' opinions, alternatively disparaging and envious, of her status as an American-returned (half) Indian researcher doing research in India. The issue of 'return' adds further complications - many anthropologists doing research at home have been trained in the West (M.N. Srinivas, for instance, was trained in Britain). Not only does this presume training in a Western pedagogy but also, as in my case, it speaks of a privileged socio-economic location which makes possible migration to Western universities. Reflecting on internal differentiations among natives becomes all the more pertinent, then, to native anthropologists.

However, while viewing the ethnographer and participants in terms of 'inbetweenness', 'multiple positionalities', and 'hybridity' is very important, this still presumes shared ethnicity between ethnographer and participants. Instead, I argue that we need to pay more attention to the changing nature of home due to newer forms of mobility - that of sizeable populations of 'First World' citizens migrating to the 'global South' primarily for reasons of lifestyle change such as lower living cost, warm climate, rebelling against the everyday demands of career and so on (Hoey 2005; O'Reilly 2007). Acknowledging these forms of mobility and migration alert us to the changing dynamics of fieldwork at home whereby the native anthropologist need no longer be doing research with the 'local' community. Rather, it is now possible for the nonWestern anthropologist to do fieldwork among Western participants in the non-West inevitably leading to further complications of positionality linked to one's location in the global hierarchy of West/non-West, and negotiations of these very locations in the dynamic site of the field where the native researcher and non-native participants meet.

\section{DISLOCATING THE FIELD}

Tired and hungry, I enter Surguru ${ }^{3}$ [...] Almost as soon as I enter, an elderly, Western man enters the restaurant. His forehead is marked with red vermilion and ash $t i k a^{4}$. I want to talk to him but am unsure of approaching him. We finish our meals almost at the same time. He leaves before me and I run out to catch him [...] he tells me he is French and has lived in Puducherry for almost 17 years [...] I ask him about the tika, he says he has just been to a Kali temple-he also says that he and his wife are Buddhists [...] He has to go and I can't carry on my conversation with him. As I turn around to walk away, 
a crippled beggar, dragging himself on his arms calls out to him, 'Monsieur' [...] . (Edited field notes)

Interested in exploring the continuing popularity of imaginaries of 'spiritual India' and their implications for global politics between India and the West, I decided to do fieldwork in Puducherry, a South Indian city, home to Sri Aurobindo Ashram (hermitage) which is a popular destination for spiritual tourists (Sharpley and Sundaram 2005). In The Imam and the Indian, Amitava Ghosh expresses his surprise when he realises that almost everyone in the small Egyptian village, his field, was a traveller, 'many of them had worked and travelled in the sheikdoms of the Persian Gulf [...] some had been to the Yemen as soldiers [...] a few had visited Europe [...] it seemed to me sometimes that every man in it was a traveller' (cited in Clifford 1997, 1-2). The village, as Ghosh realises, is part of global networks of travel and movement. Puducherry similarly is located within networks of travel and movement. In saying this I am not suggesting that everyone there has the economic means to travel elsewhere. But it is important to point out the ways in which Puducherry, just like the small Egyptian village, demonstrates the intersection of the local and the global via colonialism, domestic and international tourism, and the global reach of 'Indian' spirituality.

Puducherry was a French colony between 17th-2oth century within what was predominantly British India, and continued to remain under French rule until 1954, seven years after Indian independence from the British. The continuing legacy of French imperialism is evident today not only in terms of the French-style buildings in the 'French Town' of the city but also in terms of French tourists and expats. The ethnographic vignette above is testimony to this continuing legacy - it was not coincidental that the man I met happened to be French, nor was it just luck that the beggar knew enough French to call out to the man as, 'monsieur'.

Indo-French ties in Puducherry go beyond architecture and tourism into the sphere of spirituality. Sri Aurobindo Ashram is a popular spiritual centre for devotees and visitors or tourists. The ashram was founded in 1926 on the philosophical and spiritual tenets of Sri Aurobindo Ghose (1872-1950) who was later joined by the French woman Mirra Alfassa (1878-1973), referred to simply as 'the Mother.' Today it is a thriving organisation with a school, nursing home, library, archives, common dining room, playground, shops and guest houses spread through the city. The ashram has more than 1000 formal members of different nationalities, called ashramites, whose basic needs of food and accommodation are taken care of by the ashram. Apart from ashramites, each year 
the ashram receives people from different parts of the country and the world volunteering to work in the ashram bakery, school, nursing home, and other work units. Also, many devotees and tourists go there simply to visit the ashram and pay homage at the Samadhi (Sri Aurobindo and the Mother's tomb).

Over the course of my fieldwork between 2013 to 2015, I met people from Australia, England, France, Germany, America, Israel and the United States, in the guest houses, cafes, ashram dining hall, and sometimes casually on the streets. Most of my primary interlocutors are either long term dwellers that is, those who have been living in Puducherry or India in general for anywhere between twenty and forty years ${ }^{6}$ or are frequent returnees, that is, those who have been visiting India regularly since their first visit. For many this entailed frequent return over the past twenty or more years. Some of them are ashramites whereas others are simply devotees of Mother and Sri Aurobindo but not formal members of the ashram. Yet others fall into neither category but happen to live in Puducherry because it affords them a lifestyle that they like while also giving them the physical proximity to gurus or ashrams in other parts of India.

For the anthropologist doing fieldwork at home, it is necessary to employ a conceptualisation of home/field that takes into account the ways in which it is inscribed by movement across the local and the global making it a place of heterogeneity and multiplicity (Massey 2005). While French colonialism ensured ongoing political, economic and spiritual exchanges between Puducherry and France during colonial times, today global adoption-appropriation of Eastern spirituality in the West ensures the continuing attraction of ashrams in India including Sri Aurobindo Ashram in Puducherry. Most of my interlocutors on whom I focus in this paper first came across 'Indian' spirituality (gurus, ashrams and yoga) in their youth, between the late 1960 s and mid-1980s. To most of them, a spiritual life represents an alternative to what they thought was a 'materialistic' way of life, that is, a lifestyle which emphasises career, consumerism and competition. As young people during the 196os counter-culture, many of them felt at the time that their country did not provide the kind of alternative lifestyle that they were looking for.

Often in their narratives, there was a palpable sense of disenchantment with life in their country. Thus, Robbie, an American ashramite who has been living in Puducherry for more than forty years recounted growing up in the sixties, getting involved in college politics and eventually dropping out of college, 'I became a very passionate and bitter young man'. Disenchanted with his life in America, Robbie told me, 'I travelled a lot [...] read a lot of books and for the first time in my life became a serious student. I had serious questions [...] 
eventually it pushed me toward the East'. Sally, from Western Europe, who also travelled to India toward the end of 1960 s with some friends and now has been living in India for more than thirty years said they started travelling because, 'it was no longer possible to be where we had been'. The 'East' as such and India in particular emerged as the locale of the alternative spiritual lifestyle insofar as it was seen by my interlocutors as home to ancient wisdom. As Srinivas notes, 'The American counterculture movement of the 196os, fuelled by an international cultural need to find in Indian spirituality an opposition to Western rationality and greed, led to a spiritual seeking in India as an expression of zeitgeist' $(2010,11)$. Their turn Eastward is historically rooted in colonialist and Orientalist imaginaries of India as the founding ground of ancient spirituality and wisdom (Narayan 1993). In Orientalist discourse including that of French Indologists such as Anquetil Duperron (1731-1805) and subsequently in the discourse of Indian nationalists trying to challenge Western imperialism, 'The West was characterised by rationality, progress, quantification and secularism, whereas India came to represent a spiritual return to a superior past characterised by unity and harmony' (Korpela 2010, 1307).

In the 1960s in America and parts of Europe gurus and ashrams gained prominence through popular culture such as the Beatles' romance with Maharishi Mahesh Yogi. Gurus from India set up ashrams and yoga centres in the US, a process that continued well into the next two decades even though the counterculture movement had waned by the early 1970s. And yet as part of a relatively more mainstream popular culture, India continued to represent the exotic Other, an alternative to the West because it symbolised a pre-modern spiritual past. My interlocutors' turn toward India was in search of this authentic past which they believe had been lost in the West. As one of my interlocutors put it, 'Every people has in them this inner truth [...] but in India [it] still can be felt, can be lived'. Many of my interlocutors' quests for the authentic presuppose a certain kind of India and Indians, the native as the symbol of authentic, spiritual India. The following section discusses the political implications of such a constructed subject position for me and the people I engaged with in Puducherry.

\section{INDIAN ANTHROPOLOGIST, WESTERN PARTICIPANTS}

In the previous section, in dis-locating Puducherry, I attempted to situate it out of 'the localizing strategies of traditional ethnography' (Appadurai 1991, 196) which conceptualise the field as bounded. Such a view mistakenly constructs the local - and the 'local community' - as 'closed, coherent, integrated as authentic, as 'home', a secure retreat' (Massey 2005, 6) where a homogenous 
identity is the basis of its membership. But as Clifford $(1997,19)$ asks, '[... "local" in whose terms? [...] Who determines where (and when) a community draws its lines, names its insiders and outsiders?. The problem is compounded when one recognises that the entire national geopolitical boundary, hypothetically, could serve as the 'local community' for the native or indigenous anthropologist, regional differences notwithstanding. Fahim and Helmer write, 'The concept of indigenous anthropology implies [...] the researcher's affiliation with a particular nation-state, culture, or ethnic group' (1980, 645), a very broad spectrum of affiliatory units. Thus, I, Bengali born and raised in Delhi, could apply the tag 'native' to myself whether I do ethnography in Puducherry in South India or up north in Rishikesh, by way of their inclusion within the territorial boundaries of India. Without a doubt, I am an insider by way of citizenship while my interlocutors are outsiders. One of my interlocutors, Pierre, is of French nationality. He went to Puducherry in the 1960s and has since been living in the ashram. In more than forty years, he has never once gone back to France. He says the ashram is his home. However, he has to get his visa renewed every year. So he requested the visa officer in the Chennai office to give him a residence permit. Pierre laughingly recounts that the visa officer grimly refused him saying, 'We have enough Indian citizens already'!

Pierre's funny anecdote makes a gentle mockery of the state and points to the incongruity between the state discourse and the everyday world where Pierre feels 'at home' in Puducherry. Doreen Massey explains: 'The modernist conception of nation-states or cultural isolates resonates with the billiard-ball view of the world proposed by physical mechanics. First the entities exist, in their full identities, and then they come into interaction. There is a distinct inside and outside' $(2005,72)$. However, in the everyday world which is the space of the 'field', such precise and clear-cut locations become routinely muddled and blurred. Like Pierre, many Westerners in the ashram and the city in general have been living there for more than three decades now. Or have been travelling there almost every year since before I was born! This gives them an insider position which I cannot claim for myself. For them, state discourses and practices such as visa renewal procedures and lengthy forms at guest houses for 'foreigners' trying to inscribe them as outsiders or non-Indians seemed completely pointless. Not only do many of them speak the local language, Tamil, (which I do not) ${ }^{7}$ but, more importantly, they are entrenched in the life of the ashram and the wider spiritual community. This hit home on my second visit to Puducherry:

As I reach the Guest House, ${ }^{8}$ I see Emil standing in front of the gate smoking $b i d i^{9}[\ldots]$ Since last year, Emil has involved himself in the 
Guest House work like registering people, giving them dining hall meal coupons [...] He goes into the reception to enter my details in the guests' register. Everyone here takes off their shoes at the main entrance of the Guest House ${ }^{10}[\ldots]$ certainly no one enters the office with shoes on. The office has a photograph of the Mother and Sri Aurobindo, the tiled floors are cool to the feet, there are fresh flowers from the ashram garden on the manager's table [...] it has a quiet and peaceful atmosphere and almost feels like the sanctum sanctorum of the Guest House. I am wearing canvas shoes and feel too lazy to take them off to enter the office. I ask Emil if I may enter the office with my shoes on. 'Nooo! You have forgotten already!' he exclaims good naturedly. (Edited field notes)

Emil was staying in the Guest House already by the time I arrived there for my first research trip and was still there when I returned the following year. Emil is from Finland and usually comes to India every year during Europe's winter months. He has been doing this for more than twenty years now and for the past three years whenever he goes to Puducherry, he stays in this particular guest house. He is so much a part of life there that despite his movement to and from Puducherry, he is in many ways a resident. He, like many other Westerners in India, is nevertheless suspect in the eyes of some. During fieldwork I happened to meet a Bengali Indian woman who has been teaching yoga in Paris for the past 32 years. Walking along the Ganesh temple road next to the ashram dining hall, I explained to her that I am interested in the motivations and experiences of Westerners who come to India for spirituality. Hearing this, she stopped abruptly on the street, closed her eyes for a few seconds and then opening them told me in an almost prophetic tone, 'they understand nothing of spirituality. They come here only to gawk at us, because it's cheap and because the weather is good. All they understand is mind, money and matter' I bumped into her by chance another day and in all seriousness she reiterated her sentiments, 'A student (in Paris) asked me, "How can I be spiritual"? And I told her, "You can't. You will have to be born as an Indian in your next life". Her exclusivist nationalism - perhaps fostered more strongly while living in Paris would never accept Emil as a legitimate insider. Yet I, an Indian born Hindu, in contrast to Emil was experientially distant from the sacred environment and, in that sense, hovered outside the space that Emil inhabited more 'naturally' than I did. Equally, in lightly reprimanding me for 'forgetting' to take off my shoes, was Emil implicitly commenting on another kind of forgetfulness on my part, of forgetting how to be truly Indian by overlooking the custom of taking off my shoes before entering a sacred space? 
"How is the notion of "Indian-ness" to be translated? What constitutes "Indianness"? Who defines it?' (Sinha 2005, 148). These issues emerged time and time again in Puducherry for, my 'Indian-ness', or the lack of it, often came under close scrutiny by both Indians and Westerners there. My lack of inhibitions in talking to strangers, the fact that I was now living by myself in New Zealand, had travelled alone to Puducherry and had no family there, and fluency in English made it possible for me to build close friendships with many of the Westerners there. But it often also raised incredulous comments like, 'Do you know how unlike Indian girls you are?' While the American interlocutor who had rhetorically asked me this had meant it in an appreciative manner, it left me flummoxed. What exactly are Indian girls supposed to be like? Imaginaries of Indian women, historically rooted in colonial representations, have routinely portrayed them as the absolute other to the supposedly empowered European woman (Mohanty 1991; Spivak 1988). In her study of European women backpackers in Varanasi, Korpela (2006) finds that their views on Indian women were similar to colonial perceptions of Indian women as largely traditional and passive, the ultimate symbol of India's 'backwardness'. Korpela's findings are not very different to many of my interlocutors' views about Indian women, this despite the fact that Puducherry attracts many middle-class, working, young women travelling independently or with friends from neighbouring cities such as Chennai. I found it surprising that the young women's obvious physical presence every weekend on the sea-side promenade and the numerous cafes had done nothing to counter images of Indian girls as lacking agency. And that the topos of the native woman was the marker against which my own Indian-ness or nativity came to be judged.

In her work, Spivak has regularly addressed the figure of the native who emerges as the site of cultural resources for the colonialist, in and against which the latter articulates his (and occasionally her ${ }^{11}$ ) subjectivity marked by radical difference and superiority. The native is thus produced as the native informant in that he or she is crucial to supplying the necessary information or (mistaken) knowledge about native society against which the colonial, Western self is produced as (hu)man. But the native informant himself, and more so herself, is expelled from the, 'name of Man' (Spivak 1999, 6), as his or her identity is denied the possibility of articulate subjectivity, something that Spivak brings out most successfully in her essay Can the Subaltern Speak? (1988). She argues, 'Between patriarchy and imperialism, subject-constitution and object-formation, the figure of the woman disappears [...] There is no space from which the sexed subaltern can speak' $(1988,306-307)$. The subaltern woman cannot speak because her voice is denied agency and, therefore, goes unheard by those claiming to represent her. Taking forward her exploration of the figure of the 
native woman in A Critique of Postcolonial Reason Spivak (1999) goes on to argue that, 'the typecase of the foreclosed native informant today is the poorest woman of the South' (6). As I found in my interactions with some interlocutors, indeed, the figure of the marginalised woman serves as, 'the source of value and representation for the first world' (Bhattacharjee 2001, 1197) whereby all Indian women are measured against the construct of the traditional Indian woman. ${ }^{12}$

In not inhabiting the subject position of the so-called 'Indian girl', where exactly was I located vis-à-vis my interlocutors? On the one hand, my seeming distance from the 'Indian girl' placed me much closer to my interlocutors insofar as I was perceived more like them in being independent and outspoken. The fact that I live in New Zealand away from family was taken to be a sign of my cosmopolitanism. On the other hand, my cultural and geographical distance from ideas of Indian-ness and India respectively also made me different' in their eyes. On a short visit to the neighbouring town of Thiruvanamallai, I was invited by an English man to his house for an informal session of devotional songs. Less than five minutes after being introduced to a young European man, he said to me, 'you live abroad, don't you?' I was taken aback. I was wearing salwar kameez which is a common attire among women in many parts of India, did not speak with a foreign accent and yet somehow I had been singled out as different. The young man could not explain just what it was that had led him to this assumption except, 'I just know. While living abroad had somehow marked me as different, for other people this difference (whether or not they explicitly alluded to my life in New Zealand) was also telling of my supposed inauthenticity. Yvonne is a German ashramite who has been living in Puducherry for over thirty years. I would meet her almost every evening in my Guest House garden. One evening our conversation turned to 'modern' Indians 'copying' the West. Yvonne had been telling me, 'spirituality is ingrained in every breath here, in everything you do, from morning in the food, in the mudras, everything has a deeper meaning. People may not know it but someone published all this so that I know it! Modern people are just copying the West [...]' Yvonne was referring to the texts written by Sri Aurobindo and the Mother which according to her have given her the knowledge of the deeper spiritual meaning of everything done in India. Thus, Yvonne was claiming an insider's knowledge of Indian spirituality, something that she says is now lost to Indian people themselves as they are busy becoming modern, that is, Western. I interjected, 'What do you mean when you say they are copying the West? In clothes?' Yvonne replied:

In everything. In food, in clothes, in jobs, in getting the worst. I mean 
in their married life, they don't know anything anymore about the foundation. I couldn't believe it but like there was one young (Indian) mother in Park GH and then she started talking about how they are rediscovering spirituality $[. .$.$] trying to observe and under-$ stand this by a TV! [...] When we came here yoga was called [...] asanas (postural exercise) were called asanas and yoga was yoga. Now everybody goes to yoga class. It's all copying the West [...] it breaks my heart.

In her narrative, Yvonne is highly critical of the young Indian woman who tells her that she is rediscovering spirituality through television. Interestingly, implicit in Yvonne's narrative is the insider's position that she claims for herself when she states that when she first went to India, yoga was not confused with postural exercise and was therefore more real. She thus suggests that while she as a Westerner is truly appreciative of authentic spirituality, young urban Indians have lost touch with this reality by their imitation of the West in everything from clothes through food to entire lifestyles. Yvonne continued:

$[\ldots]$ the women $[\ldots]$ Why do the shakti (a reference to Indian women as powerful since shakti is a name for the embodiment of divine feminine energy) want to be like western women? I don't know why. They don't know, they forget what they are. They forget their power. They lose their foundation. They are not aware. I don't know how much you are aware (with a small laugh). I have no idea.

Continuing her narrative of perceived inauthenticity among young Indians who are supposedly copying the West, Yvonne reserves some of her strongest criticism for Indian women, the Shakti; a criticism that is extended to me as well. She suggests by becoming more modern I am losing the spiritual power that is inherent in the good native woman by the teleological virtue of not being modern/western. Interestingly enough, as Yvonne told me in another conversation, she herself had no inclination toward becoming 'Indianised' in terms of learning how to cook Indian food, wear Indian clothes and so on, 'we are just busy following the spiritual path'. Moreover, she would often comment on what she thought was characteristic of Indian women - their deeply accommodating nature - and say that she herself could not and would not want to be like Indian women. So, while she could claim to be a spiritual insider by having gained insight and knowledge into the 'deeper meanings' of Indian life despite not becoming Indianised, I was simultaneously critiqued for having lost my inner spirituality by way of my apperceived Westernisation. Korpela writes of her European participants' views on Indian women in Varanasi, 'There is only one 
kind of Indian woman for them, and in fact, only one kind of Western woman as well' $(2006,11)$ On a similar note, my appearance and agency as a young Indian woman was interpreted by Yvonne and some other interlocutors as a sign of being Westernised for I was unlike their image of the Indian woman.

One evening I was sitting in my guest house garden and casually chatting with Yvonne and Rachel, an Israeli woman who lived in Varanasi for many years learning Hindu metaphysics and who now frequently visits India from Israel. As we were chatting, Yvonne brought out her tiffin carrier ${ }^{13}$ full of lentil soup and offered us her food. Rachel declined but I enthusiastically dunked pieces of bread into the soup. Yvonne left after some time leaving me and Rachel by ourselves. Turning to me, Rachel expressed her utter disbelief at my 'un-Indian' behaviour of sharing food from the same container as Yvonne. Rachel said she had never seen any Indian eat like that, especially in Varanasi where people are more 'orthodox'. She says that she, too, cannot eat like that anymore, 'it's in my blood now'. She says she fully believes in the logic of not sharing utensils - for hygiene. But 'you're young and modern, Western' she says. She repeats a couple of times her amazement to see me sharing food with someone else. But she also kept reminding herself that I was young and 'Western'. Unlike Yvonne, Rachel had 'gone native' ('it is in my blood now'); she wore salwar kameez, could speak in Hindi and had adopted the custom of avoiding jutha. Jutha means left over or half eaten food and is customarily not eaten by Hindus for reasons of ritual pollution, 'because it may have been touched by the first person's hand and polluting saliva' (Fuller 2004[1992], 77). The notion of jutha has traditionally also been a way of maintaining caste hierarchy, for the polluted left over food on the plate of a 'higher' caste person is considered pure enough to be consumed by a 'lower' caste person but not vice versa (Parry 2004[1979], 5). However, this history finds no mention in Rachel's understanding and adoption of high-caste Hindu customs. While Rachel explains that she follows this practice for hygiene, she balks at my betrayal of this custom as evidence of Westernisation instead of recognising it as rejection of caste practices. Further, while her own hybridity - an Israeli woman dabbling in Indian metaphysics - posed no problem to herself, hybridity on my part - a Hindu woman who rejects caste practices without denouncing Hinduism per se - was seen as symptomatic of inauthenticity.

What are the implications, then, of the various scenarios discussed in this section? Undoubtedly, insofar as Pierre and Yvonne have been living in Puducherry for decades, and Emil and Rachel are frequent returnees to India, they are insiders to the ashram life there. They have formed ties of intimacy and care with other ashramites, visitors and locals. On the other hand I was an 
outsider, for I was new to the ashram, not a devotee, and I was there to learn more from them about the ashram life and their lives in India. But their assertions of insidership whether that be via performance of Indian-ness through adaptation-appropriation of Hindu customs such as taking off shoes or not eating jutha or via laying claims to the supposed Indian essence of spirituality without performing Indian-ness were often legitimised by taking recourse to the imaginary figure of the non-modern native. While I had no illusions from the very beginning that I occupied shifting locations - sometimes an insider, sometimes an outsider - in the field, I had not quite expected to find that the fictional character of the native would come to serve as the benchmark against which I appeared to be an outsider. As already noted, anthropologists have rightly pointed to the problems inherent in applying the label, native, to someone doing fieldwork in one's own country. However, in my case, I could not inhabit the position of the undisputed insider not simply because there can be no such position but because the global 'North' continues to produce the impossible fiction of the authentic native.

\section{AN INDIAN AMONG INDIANS}

The native, I have argued so far, is a fiction rooted in cultural essentialism which attempts to create the Other as a monolithic, fixed (non)entity. I have also tried to demonstrate that my interlocutors, when they found me not so Other to them after all, tried to fix me in the slot of the inauthentic Other. Clearly, I reject the idea of the native as fixed. But lest it seem that I am trying to claim for myself and Indians as such the position of mobile hybridity, let me turn again to Spivak (1999) who is critical of 'postmodern postcolonialist' academics positioning themselves as 'triumphalist self-declared hybrid(s)' (361). She argues that mobility and hybridity are the specific reserve of the elite from postcolonial nations whereas other postcolonial critics like Bhabha use literary deconstruction and, ' $[. .$.$] other critical/philosophical discourses$ [...] to privilege hybridity, as in his deployments of mimicry as well as in his influential theoretical trope of the third space'. For Spivak, 'a celebration of the affirmative power of hybridity or the third space is always muted by a simultaneous attention to the mode of production of such celebratory marginalized articulations, spaces, and/or characters' (Ray 2009, 47).

As part of fieldwork and a gesture of gratitude to the ashram, I volunteered to rinse dishes every afternoon in the ashram dining hall. During the two hours of washing, I would greet and wave to my interlocutors as they walked in to the washing section to hand over their dishes. Often a Bengali woman, Rina $d i^{14}$, who had migrated to Puducherry from Kolkata with her two young children, 
co-volunteered with me. I later found out her husband had lost his job and she was struggling to make ends meet. One afternoon when I was cheerfully greeting my friends and acquaintances over the din of the clanging dishes, Rina $d i$ who can barely speak English remarked to me wistfully, 'onek foreigner der cheno tai na?' ('You know many foreigners, don't you?'). Her tone made me realise that my proximity to 'the foreigners' was not simply the result of my friendliness or their generosity in giving me their time (although it was that too). My socio-economic position was the specific condition of the possibility of these relations. While my fluency in English brought me closer to my Western interlocutors even though many deemed me to be inauthentic, the same thing put me at a distance from those like Rina di despite my brown skin and being born a Bengali. To be fluent in English as a postcolonial Indian means not only to be verbally proficient in it but to virtually inhabit the language such that speaking-living the language describes, 'the subtlest kind of cultural and epistemic transformation, a kind of upward race mobility, an entry, however remote, into a geopolitical rather than merely national "Indian"-ness' (Spivak 1993, 135) Incidentally, my fluency in English does not go unnoticed in New Zealand where people have often remarked to me, 'You speak English so well!'. In annoyance, I often point out that centuries of British colonialism is bound to have some impact on my subjectivity. And yet, clearly, my subject position is that of an urban, upper-caste, middle class, 'English educated ${ }^{15}$, now-living-inthe-west academic, reflecting a certain political and social mobility that Rina di does not have. Thus, it is an acknowledgement of my own privileged socioeconomic position vis-à-vis other Indians in the field who cannot physically or metaphorically move across the socio-economic and cultural worlds as I do that keeps me from suggesting a mobile hybrid identity in exchange for the imagined identity of the native.

\section{CONCLUSION}

Increased movement across national borders and changing patterns of transnational mobility force us to think beyond not only the binary of white anthropologist/native subject but also beyond the paradigm of native anthropologist/ native subject. As I have shown in this paper, I and my interlocutors occupy multiple spatio-political locations - even as I moved from the Global South to the North, they moved from the Global North to the South, where I returned to do research among them. These movements clearly had significant ramifications for how I, as a female Indian anthropologist doing fieldwork in India, was constructed by them even as they claimed an authorial position for themselves. It was as if their own authenticity was measured against my apperceived lack of it. In the introduction, I asked if the situation had reversed now whereby my 
Western interlocutors had emerged as native informants for me. The simple answer is no, not because they did not inhabit a partial insider position (they did) but because they constructed a subject position of the native for me to fill in which I could not (since that native is anyway a construction, and my socio-economic location places me in a position of adapting multiple identity markers). In some ways, then, I was the native informant for my interlocutors albeit via negativa which means I informed them of what, for them, the inauthentic native is. Global asymmetries that produce an authentic spiritual India simultaneously produce irresolvable tensions between the privileged native anthropologist doing fieldwork at home and interlocutors from the global North. Even as the native 'as a blank', using Spivak's terms, has always been an imperialist myth, it was precisely the mythical native that posed limits to my authorial agency. Thus, the variability afforded by the multiple locations that I and my interlocutors occupied in the everyday context was in constant negotiation with the abstract but fixed category of the authentic native. In this paper, I have critiqued such fixed categories by demonstrating the heterogeneity of our locations. And yet I am mindful of substituting ideas of the native as fixed with a counter-construction of the native as hypermobile. My mobility, after all, is a result of a privileged socio-economic position not inhabited by many in my country. Neither notions of absolute fixity nor those of absolute fluidity enable us to understand the relations between the anthropologist and interlocutors. Instead, this paper has argued for paying close attention to the complexities of our situatedness in global political asymmetries to better understand the dialectic of fixity and fluidity in the construction of the native anthropologist.

NOTES

1 Tuhina Ganguly recently submitted her PhD thesis at the Department of Sociology and Anthropology, College of Arts, University of Canterbury, New Zealand. Her research interests include lifestyle migration, tourism, guru movements, and spirituality.

2 In using the term 'spiritual seekers', I am referring to a wide range of people in terms of age, nationality, beliefs and faith and so on, most of whom travelled to India for spirituality or an alternative lifestyle to a 'consumerist, materialistic' lifestyle in their country of birth. I am aware that the term 'spiritual seekers' is inadequate in that it does not capture the specificities of their lives, their different experiences and the depth of their being. However, given the limited space, I have had to retain the phrase 'spiritual seekers' for convenience. I do hope this indiscretion on my part will be forgiven. 
3 Surguru is a chain of restaurants in Puducherry serving vegetarian meals.

4 Sacred ash smeared on one's forehead.

5 Sri Aurobindo's school of Yoga is called Integral Yoga.

6 Most of them do not have Indian citizenship or permanent residency. Some cited the numerous bureaucratic obstacles to obtain these although they wanted to become a citizen, others however were not inclined to become citizens since then they would have to obtain a visa to visit their own country every time they travelled there to visit family.

7 I am fluent in Hindi, Bengali and English.

8 One of the ashram guest houses.

9 A local, low cost cigarette made from tendu leaves.

10 It is a common Hindu custom to take off one's shoes before entering a temple or a sacred place as a mark of respect and devotion.

11 Spivak speaks of Anglo-American women's imperialism in Three Women's Texts (1985) reproduced in A Critique (1999) as part of the chapter titled 'Literature'. Her readings of Jane Eyre, Wide Sargasso Sea and Frankenstein point out the ways in which the white European or American woman remains the normative universal feminine subject, thus, reproducing imperialist structures of casting away Other women as less-than-woman.

12 Certainly this is not to say that Indian women are not marginalised. Spivak herself has warned against the tendency among Indian elite women academics to not critique the problematic position of especially lower class, lower caste, rural women in India in order to decry the Western disavowal of Indian women's agency. Nevertheless, marginalised Indian women have played a highly instrumental role in grassroots movements such as the Chipko Movement, Narmada Bachao Andolan and so on. My critique of some of my interlocutors' comments about Indian girls is that a lumping together of Indian women completely overlooks the specificities of socio-economic positions of women.

13 A steel lunch box with containers stacked one on top of another.

$14 D i$ is short for didi which means elder sister in Bengali. 
15 By 'English educated', I mean that I have been educated in schools and colleges where the medium of instruction was English. As opposed to this, many state government and central government run schools in India have the vernacular as the medium of instruction.

\section{REFERENCES}

Abu-Lughod, Lila. 1991. 'Writing Against Culture'. In Recapturing Anthropology, edited by Richard G. Fox, 137-62. Santa Fe, New Mexico: School of American Research Press.

Appadurai, Arjun. 1988. 'Putting Hierarchy in Its Place'. Cultural Anthropology 3 (1):36-49. doi:http://dx.doi.org/10.1525/can.1988.3.1.02aooo4o.

- 1991. 'Global Ethnoscapes: Notes and Queries for a Transnational Anthropology’. In Recapturing Anthropology, edited by Richard G. Fox, 191-210. Santa Fe, New Mexico: School of American Research Press.

Ben-Ari, Eyal and Jan Van Bremen. 2005. 'Asian Anthropologies and Anthropologies in Asia: An Introductory Essay'. In Asian Anthropology, edited by Jan Van Bremen, Eyal Ben-Ari and Syed Farid Alatas, 3-39. Oxon and New York: Routledge.

Bhattacharjee, Sukalpa. 2001. 'Towards a Theory of Native Informant'. Economic and Political Weekly 36 (14/15):1194-1198.

Clifford, James. 1997. Routes: Travel and Translation in the Late Twentieth Century. Cambridge, Mass: Harvard University Press.

Das, Veena. 1995. Critical Events: An Anthropological Perspective on Contemporary India. Delhi: Oxford University Press.

Fahim, Hussein and Katherine Helmer. 1980. 'Indigenous Anthropology in Non-Western Countries: A Further Elaboration'. Current Anthropology 21 (5): 644-63.

Fuller, Christopher J. 2004 (1992). The Camphor Flame: Popular Hinduism and Society in India. Princeton and Oxford: Princeton University Press.

Ghosh, Amitava. 1994. In an Antique Land: History in the Guise of a Traveler's Tale. New York: Vintage Books. 
Gordon, Lewis R. 2013. 'On the Temporality of Indigenous Identity'. In The Politics of Identity: Emerging Indigeneity, edited by Michelle Harris, Martin Nakata and Bronwyn Carlson, 60-78. Sydney, Australia: UTs ePress.

Halstead, Narmala. 2001. 'Ethnographic Encounters. Positionings Within and Outside the Insider frame'. Social Anthropology 9 (3):307-321.

Hoey, Brian A. 2005. 'From Pi to Pie: Moral Narratives of Noneconomic Migration and Starting Over in the Postindustrial Midwest'. Journal of Contemporary Ethnography 34(5):586-624.

Jackson, Anthony. 1987. 'Reflections on Ethnography at Home and the ASA'. In Anthropology at Home, edited by Anthony Jackson. page numbers ASA Monographs 25. London and New York: Tavistock Publications Ltd.

Jahan, Ishrat. 2014. 'Revisiting 'Nativity': Doing 'Anthropology at Home' in Rural Bangladesh'. Anthropol 2:123. doi:http://dx.doi.org/10.4172/23320915.1000123. http://www.omicsonline.org/open-access/revisiting-nativity-doing-anthropology-at-home-in-rural-bangladesh-2332-0915.1000123. php?aid $=24647$

Korpela, Mari. 2006. 'I'm not Like Indian Women. Reflections of Young European Women in Varanasi, India.' Jargonia 4(9).

- 2010.'A Postcolonial Imagination? Westerns Searching for Authenticity in India'. Journal of Ethnic and Migration Studies, 36 (8):1299-1315.

Kuwayama, Takami. 2005. 'Native Discourse in the "Academic World System": Kunio Yanagita's Project of Global Folkloristics Reconsidered'. In Asian Anthropology, edited by Jan Van Bremen, Eyal Ben-Ari and Syed Farid Alatas, 97-116. Oxon and New York: Routledge.

Leibing, Annette and Athena McLean. 2007. "Learn to Value Your Shadow!" An Introduction to the Margins of Fieldwork. In The Shadow Side of Fieldwork: Exploring the Blurred Borders between Ethnography and Life, edited by Annette Leibing and Athena McLean, 1-28. Malden, MA: Blackwell Publishing.

Massey, Doreen. 2005. For Space. London, Thousand Oaks and New Delhi: Sage Publications. 
Mohanty, Chandra Talpade. 1991. 'Cartographies of Struggle: Third World Women and the Politics of Feminism'. In Third World Women and the Politics of Feminism, edited by Chandra Talpade Mohanty, Ann Russo and Lourdes Torres, 1-49. Bloomington and Indianapolis: Indiana University Press.

Moroşanu, Laura. 2015. 'Researching Coethnic Migrants: Privileges and Puzzles of "Insiderness"'. Forum Qualitative Sozialforschung/Forum: Qualitative Social Research 16 (2). http://www.qualitative-research.net/index.php/fqs/article/ view/2371

Narayan, Kirin. 1993. 'How Native is a "Native" Anthropologist?'. American Anthropologist 95 (3): 671-86.

O’Reilly, Karen. 2009. 'Going “Native”. In Key Concepts in Ethnography, 88-93. London: sAGE Publications Ltd.

- 2007. 'Emerging Tourism Futures: Residential Tourism and Its Implications'. In Going Abroad. Travel, Tourism and Migration, edited by Geoffroy, C. and R. Sibley, 144-57. Newcastle: Cambridge Scholars Publishing.

Parry, Jonathan P. 2004 (1979). Caste and Kinship in Kangra. Oxon: Routledge.

Ray, Sangeeta. 2009. Gayatri Chakravorty Spivak: In Other Words. West Sussex: Wiley-Blackwell Publications.

Ryan, Louise. 2015. "Inside" and "Outside” of What or Where? Researching Migration Through Multi-Positionalities'. Forum Qualitative Sozialforschung / Forum: Qualitative Social Research 16 (2). http://www.qualitative-research. net/index.php/fqs/article/view/2333

Sharpley, Richard and Priya Sundaram. 2005. 'Tourism: A Sacred Journey? The Case of Ashram Tourism, India'. International Journal Of Tourism Research $7(3): 161-171$.

Sinha, Vineeta. 2005. "Indigenizing” Anthropology in India: Problematics of Negotiating an Identity'. In Asian Anthropology, edited by Jan Van Bremen, Eyal Ben-Ari and Syed Farid Alatas, 139-161. Oxon and New York: Routledge.

Spivak, Gayatri Chakravorty. 1988. 'Can the Subaltern Speak?' In Marxism and the Interpretation of Culture, edited by Cary Nelson and Lawrence Grossberg, 271-313. London: Macmillan. 
- 1993. 'The Burden of English'. In Orientalism and the Postcolonial Predicament: Perspectives on South Asia, edited by Carol A. Breckenridge and Peter van der Veer, 134-157. Philadelphia: University of Pennsylvania Press.

- 1999 A Critique of Postcolonial Reason: Toward a History of the Vanishing Present. Cambridge, MA and London, England: Harvard University Press.

Srinivas, Tulasi. 2010. Winged Faith: Rethinking Globalization and Religious Pluralism through the Sathya Sai Movement. New York: Columbia University Press.

Tsing, Anna. 200o. 'The Global Situation'. Cultural Anthropology 15 (3):327-6o. 